\title{
A Catalogue of the Facial Behavior Patterns of Japanese Preschool Children
}

\author{
Toshiyuki SANO* \\ Department of Anthropology, Faculty of Science, \\ University of Tokyo, \\ Hongo, Bunkyo-ku,Tokyo 113 Japan
}

\begin{abstract}
$A B S T R A C T$ An ethology-based catalogue of twenty five items of facial behavior patterns is presented based on a research of Japanese day nursery children. Comparisons are made between the published and this catalogue in order to make clear the differences in ways to list facial behavior patterns and culturally influenced behavior patterns. It can be concluded that there is no developmental change in facial behavior patterns from one to five years old, though some cultural differences can be observed in other body patterns among preschool children, that the measurements of hedonic tone of facial behavior patterns seem to be the same cross-culturally, and that it is necessary to do research on the general meaning of the 'reassurance' behavior caused by the facial display observed in this research.
\end{abstract}

\section{INTRODUCTION}

Among human behavior patterns, special attention has been paid to facial behavior patterns. Howevr, it is not possible to state the study of facial behavior patterns has been fully done. For example, one need only note the long period between DARWIN's (1872) study of human expression and the recent studies of this kind (Blurton Jones, 1967, 1971; BranNigan and Humphries, 1972; Grant, 1968; van Hoof F, 1971). The reasons why there have been so few works in that period can be said to be the difficulty in developing appropriate methods to study human behavior (e.g., how to record, how to cate-

*Department of Anthropology, Staford University, Stanford, CA 94305 U.S. A.

Article No. 8213 gorize) as well as a lack of appropriate theoretical frameworks.

The biological study of human behavior seems to depend theoretically and methodologically on animal ethology established by Lorenz (1965) and Tinbergen (1963). Human ethology consists of an observation and an objective description of behavior patterns in natural situations. There have been two types of descriptions of human facial behavior patterns, one using features in each unit, such as eyebrow, eye, nose, lip and others (Grant, 1969 ; Blurton Jones, 1971; Brannigan and Humphries, 1972 ; McGrew, 1972), the other with the features which represent whole face, combining the units (Young and Gouin Dḱcarie, 1977). These lists were made from observations among Western people. 
There are some differences in the way how to list the items among the published catalogues. BLuRTon Jones (1971) and GRANT (1969) described the behavioral elements by dividing the face into several units. On the contrary, Young and GouIN DÉCARIE (0977) did so by conbining each unit, taking into cnnsideraton the fact that each unit is always expressed as a complex although they can be moved independently and that if one unit is moved, the rest of the face functions as 'ground.' MCGREW's list (1972) is the former type, though it is not arranged according to the former type seems to contribute to making criteria for the description or recording of behavior patterns and may be based on considering the relationship among behavior elements such as the complexity of such elements. The latter type seems to contribute to connecting an item with an emotion. In either case, however, practical considerations (e. $g^{\circ}$, length and complexity) were taken into account. The type of listing to take seems to depend upon the aims of research. The catalogue described below was made based on the former type of listing because of the convenience of recording behavior patterns and the ease of comparing the results with the published catalogues.

In order to prepare a complete human ethogram, it is necessary to describe the behavior patterns through observation among people of different cultural backgrounds. The purpose of this report is to present a catalogue of the facial behavior patterns of Japanese children and to discuss : such aspects as cultural differences and the development of facial behavior by comparing them with the results of the previous literature.

\section{SUBJECTS AND PROCEDURE}

The children of a public day nursery in a suburb of Tokyo, whose parents were economically in the lower middle or middle class, were observed during meal and free play periods in the morning and the afternoon. The age of the children ranged from three months to six years. They were divided into six classes according to their ages. This report is based on the observation of the following classes: the second (five females and five males of 1.4 to 2 years of age), the third ( $\mathrm{six}$ females and six males of 2 to to 3 years of age) and the fourth (eleven females and five males of 3 to 4 years of age). The observer stood or sat at the spots which were convenient for observation, moved when the observer seemed to interfere with the children's play and followed the moving children.

The method of recording was to write down the behavior patterns which the children showed in social situations as the situations themselves. Focal sampling and ad libitum sampling (A LTMAN, 1974) were employed throughout the observation period from July, 1978 to May, 1979, and V.T.R.was used between April and May, 1979. Total observation time was 480 hours.

Several stages were needed to make the final catalogue of facial behavior patterns. In the early stage of the observa* tion, enough time was spent to obtain 
ample experience with observation and a preliminary list of the behavior patterns was not made at this time. The moving directions and body movement types were recorded. At the end of the early stage, a tentative catalogue was processed by lumping and partitoning the descriptive data. Finally, the definition and some situational examples were completed in each category considering the previous literature, especially MCGREW(1972). Inter-observer reliability testng was not done, since determining the quality of the observation might not depend on reliability but on replication as BLURTON JONES(1972) discussed. Even without such tests, this report could serve to testify the quality of the previous literature and to reveal the differences in elements between this catalogue and published ones.

\section{RESULTS: DESCRIPTION OF THE ELEMENTS OF FACIAL BEHAVIOR PATTERNS}

Each behavior element is described in the following way: (A)definition, (B) situational examples, (C) explanations of such aspects as function, performance or combinations with other behavior patterns. Each element of facial behavior patterns listed below occurred mostly with each othes as well as with various behavior elements of other parts of body.

1) Asymmetrical Mouth

A. The mouth is closed. Either of the mouth corners is pulled outward and upward or downward. The appearance of the mouth is non-symmetrical.

B. a, while looking at the observer through the window; $\mathbf{b}$, when the teacher was walking toward the subject after an other child began to cry whose play-car bumped in to the subject's play-car.

C. This behavior pattern occurred too infrequently to infer function. It seems to occur when a child gets embarrassed by an other's incomprehensible behavior.

2) Blink

A. Both eyelids are lowered and raised rapidly and successively. This movement generally occurs singly. However, the movemenrs repeated less than five times are included.

B. a, when an other child standing nearby began to move and wave an object in his hands; $\mathbf{b}$, when a child stopped passing by another child who began to wave his own arms suddenly.

C. 'Blink' seems to be a protective response to the sudden movements which happen near the performer's head. This is in contrast to the eye-aversion and fleeing since it may allow the performer to continue to get some information about the opponents.

3) Close Eyes

A. The eyelids are closed and remained so for a few seconds. The duration of the closing eyelids is longer than that of 'Blink.'

B. 1. when crying. As a response to an other child's sudden movements; a, when an other child standing near began to move and sway arms; $\mathbf{b}$, at the time when the subject was hit on the head or arm by the other child.

C. This behavior pattern may be one of the "Cut-off" movements described by 
Table 1. The catalogue of facial behavior pat terns. Numerals are the number of the items of McGrew (1972) and Young \& GouIN DÉCARIE (1977). *means slight movement. $\mathrm{P}, \mathrm{U}$ and $\mathrm{N}$ are abbreviations of Positive, Undifferenciated and Negative hedonic tone respectively.

YOUNG \& GOUIN MCGREW
DÉCARIE (1977) (1972)
P U N N

4 Close Mouth Smile $1^{*}$

15

2

9

13 Open Mouth 4

14 Open Mouth Smile 5

15 Play Face 6

19 Slight Open 3

Mouth Smile 10

\begin{tabular}{|c|c|c|c|c|}
\hline \multirow[t]{2}{*}{2 Blink } & & 4 & 9 & 2 \\
\hline & & & 12 & \\
\hline \multirow[t]{3}{*}{3 Closed Eyes } & & $19 *$ & 2 & 4 \\
\hline & & & 6 & \\
\hline & & & 10 & \\
\hline 5 Droop & $9^{*}$ & 11 & & - \\
\hline \multirow[t]{6}{*}{6 Frown } & 3 & 3 & 1 & 6 \\
\hline & & 10 & 2 & \\
\hline & & 19 & 4 & \\
\hline & & & 8 & \\
\hline & & & 11 & \\
\hline & & & 12 & \\
\hline
\end{tabular}

8 Lower Lip Forward

10 Narrow Eyes

8
2
$10 *$

$\begin{array}{lll}2 & 10 * & 1 \\ 3 & & 2\end{array}$

44

55

68

7

8

10

11 Normal Face

17 Raised Eyebrows

$$
11
$$

21 Slightly Open Mouth

23 Tightly Closed

Mouth

24 Wide Eyes

12

8

16 Pout

18 Red Face

$\begin{array}{cc}11 & 6 \\ 14^{*} \\ 15^{*} \\ 18\end{array}$

25 Wrinkled Nose 3

\begin{tabular}{|c|c|c|}
\hline 5 Wrinkled Nose & $\begin{array}{r}1 \\
2 \\
5 \\
11\end{array}$ & 10 \\
\hline 7 Kidney Mouth & $\begin{array}{l}2 \\
6\end{array}$ & 13 \\
\hline 9 Mouth Corners Down & $\begin{array}{r}9 \\
12\end{array}$ & 13 \\
\hline 12 Oblong Mouth & $\begin{array}{l}1 \\
3 \\
4 \\
5\end{array}$ & 13 \\
\hline 16 Pout & 8 & 12 \\
\hline 18 Red Face & $\begin{array}{r}1 \\
3 \\
4 \\
9 \\
11 \\
12\end{array}$ & 14 \\
\hline 20 Sad Frown & $\begin{array}{r}6 \\
9 \\
10\end{array}$ & 13 \\
\hline 22 Square Mouth & 10 & 13 \\
\hline
\end{tabular}

1 Asymmetrical Mouth

Chance(1962) who suggted that "Cut-off" movements or postures seem to reduce the motivation of fleeing from or becoming aggressive toward the opponents.

4) Close Mouth Smile

A. The mouth is closed and the mouth corners are upward.

B. a, a child showed this smile to an other child after drinking during meal time; $\mathbf{b}$, when a teacher touched the head of a child and praised him at the end of meal time; c, when the eves of both the child and the obserer met; $d$, while a child was looking at himself in the mir- 
ror.

C. This 'smile' seems to occur occasionally when the eyes of child meet with the other's. The interactions between children, or child and adult with active movements infrequently succeed this 'smile.' This behavior pattern seems to occur in greetings between friends, as a reassurance of friendly intentions and upon receiving praise or a material reward as McGREw(1972) described.

\section{5) Droop}

A. The upper eyelids are lowered, but not closed completely. The head is in the normal position or slightly tilted forward. The gaze direction is occasionally toward the hands on the tummy or the feet.

B. a, after being told by a teacher "You are pretty"; b, while being scoded by a teacher with both hands being put on the tummy.

C. 'Droop' appears to be an element of submissive or embarrassment postures and seems to function in "Cut-off" postures as CHANCE (1962) suggested.

\section{6) Frown}

A. The eyelids are more open than in the normal position. The eyebrows are more or less raised so that they have an arched appearance.

B. 1. In agonistic situations: a, while shouting, when a toy was taken away from the subject. 2. When looking at an other child's face: a, during meal time, with "Narrow Eyes," an open mouth and vertical furrows between the eyebrows.

C. 'Frown' appears to occur in stressful or uneay situations. Children also showed
'Frown' in response strong sunny light. MCGREw (1972：45) stated that "Low Frown occured in agonistic situations and was of ten seen significantly with beating (BLURTON JONES, 1967), often preceding as well as during attack and threat." However, ni this study, one-to three-year-olds infrequetly showed this behavior pattern in such situations, and three- to five-yearolds occasionally showed 'Frown' in such situatons. Children also show this behavior pattern when they put a piece of food, e.g., bread or a spoonful of soup in to the mouth.

7) Kidney Mouth

A. The lower jaw is dropped and/or is moved forward so the mouth is open. The mouth corners are pulled outward and downward. The appearance is like the kidney.

B. $\mathbf{a}$, at the beginning of crying; $\mathbf{b}$, when the intensity of crying has weakened; c, when a child saw the observer at the early stage of observation.

C. The function of this behavior pattern is unknown. Since the direction of pulling of the mouth corners is contrary to that of 'smile,' this seems to be one of the examples of DARWIN's(1872) "Principle of antithesis."

8) Lower Lip Forward

A. The lower lip is pushed up and out so that it protrudes forward. The upper lip is sometimes hidden behind the lower lip.

B. 1. At the beginning of crying: a, after noticing the observer; $\mathbf{b}$, while being scolded by the teacher. 2. When something detestable happened: a, during lunch 
time, when the teacher brought a piece of food in to the mouth of child; $\mathbf{b}$, after being held by mother, when mother began to put him down at about two years age.

C. This behavior pattern seems to occur when a child becomes anxious or displeased.

9) Mouth Corners Down

A. The mouth is closed or slightly open. The mouth corners are pulled outward and downward. The appearance of the mouth is like the shape of a circumflex accent.

B. 1. Just before crying. 2. When something detestable happened to a child: a, when the teacher brought away a toy from a child.

C. This behavior patten seems to be an expression of dissatisfaction or misgiving. 10) Narrow Eyes

A. The upper and lower eyelids are more closed than in the normal position.

B. 1. While crying. 2. As a response to an other child's sudden movement: a, when the other child suddenly began to move his arms near the subject. 3. In combination with other behavior patterns such as 'Frown,' 'Open Mouth' and vocalization, 'Slight Open Mouth Smile' of 'Open Mouth Smile.'

C. 'Narrow Eyes' occurs frequently with other various behavior patterns. There seem to be two types of this behavior pattern. One is with emphasis on the outer ends of the eyes, e. g., with 'Frown' The other is with emphasis on the outer ends of the eyes, e.g., with 'Slight Open Mouth Smile' or 'Open Mouth Smile.' The former seems to rep- resent the fact that the performer may be friendly, the latter seems to function as a threat. This behavior pattern also appears to occur as a protective response. 11) Normal Face

A. The muscles of the face seem to be relaxed. The mouth is usually closed. Thc positions of the eyebrows and eyelids are neutral. There are no wrinkles on the surface of the face.

B. 'Normal Face' is seen in various social and non-socal situations.

C. 'Normal Face' was only recorded if this occurred in situations where this might be unexpected in this study as McGrew(1972)did. One- to two and half year-olds reveal a 'Normal Face' when they were taking away objects from the other child.

12) Oblong Mouth

A. The mouth corners are fully or moderately pulled outward, but are not in the shape of an acute angle. The mouth is not fully open and assumes a squared appearance along the horizontal axis.

B. a, a sitting child showed 'Oblong Mouth' to the other child who passed by from behind the subject; $b$, with vocalization when the observer passed the child a toy, which the latter had dropped on the floor.

C. 'Oblong Mouth' seems to have a function of appeasement as MCGREw (1972) suggested. He added that it seemed to involve reassurance. However, this function seemed not to happen in this study.

13) Open Mouth

A. The mouth laterally and its appearance is ' $\mathrm{O}$ ' shaped. The mouth corners 
are pulled outward or not so.

B. 1. With strong or loud vocalization: crying, shouting or laughing and when imitating the vocalization of animals. 2. Without vocalization: $\mathbf{a}$, when a child was lifted up by the teacher; $\mathbf{b}$, when the child encountered the obesrver ; c, children exhibited 'Open Mouth' face-to-face in turning toward each other.

C. 'Open Mouth' is occasionally linked to 'Narrow Eyes' and various kinds of vocalization, and is seen as one of the face to-face games.

14) Open Mouth Smile

A. The mouth is open and the mouth corners are pulled outward and upward. Both upper and lower teeth are exposed. This has an oval or half-moon appearance along the horizontal axis and is occasionally combined with 'Narrow Eyes.'

B. a,after a child vocalized toward a younger child; $\mathbf{b}$, after a child patted the other child sitting next to him on the shoulder; c, while running in a group in free play.

C. This behavior pattern occurs more simultaneously with active body movements, e. g., hopping, chasing and wrestling, than other smile: 'Close Open Smile' and 'Slight Open Mouth Smile.' Children show this 'smile' with or without vocalization in response to another's curious gesture and failure to do something. Some children show the 'Open Mouth Smile' soon after they are looked at by the other child whom they have hit. This suggests that this behavior pattern may function to reduce another's intention of retaliation.
15) Play Face

A. The mouth it open widely. The mouth corners are pulled outward and upward. The teeth are not exposed, or the tips of the upper teeth are visible.

B. a, while wrestling; b, when suddenly beginning to run together; c, while seeing the others making a noise and turning around themselves.

C. 'Play Face' occurs without vocalization or sometimes with it. Even in the latter case, this behavior pattern remained after the end of the vocalization. 'Play Face' occurs while running in a group, and looking at another with "Play Crouch" which seems to function as a play invitation, and occurs in "rough-andtumble play" or "quasiagonistic" situation and is succeeded by more intense body movements as BLURTON JONES (1967) MCGREW(1972) described.

16) Pout

A. The lips are fully retracted inward, pushed forward and sometimes turned outward. This occurs simultaneously and with the dented cheeks.

B. a,projecing the subject's own face to another's after the latter ignored his play invitation; b, after shouting "No! " when other child pushed away the large wood block being used by the subject; c, when being scolded by the teacher.

C. 'Pout' seems to be occasioned by unexpected factors interfering wih ongoing movement and appears to express "sulkiness."

17) Raised Eyebrows

A. The eyebrows are raised rapidly and maintained in that position from less 
than one second to a few seconds. They have an arched appearance.

B. a, when looking at the face of a peer sitting beside the child at the table (duration was about one second) b, when changing the glance from the observer to the teacher.

C. This behavior pattern occurs infrequently among one- to three-year-olds during the meal time. MCGREW (1972: 43) described it as follows: "Like adults, children appear to use eyebrow flashing in frienḍly greeting." However, 'Raised Eyebrow' was not seen in such a situation in this study. Eibl-Eibesfelt (1975) presented the scheme of the various meanings of eyebrow lifting.

18) Red Face

A. Some parts of the facial skin, mostly on the cheeks, forehead and nose, are reddened.

B. 1. While a child cried furiously: a, while a child was standing and crying with his face up after he had chased an other child who had taken away his toy but not able to get it back.

C. 'Red Face' appears to occur simultaneously with vocalization. This was not seen occurrng in such situations as described by BLuRTon Jones (1972) where a child seemed highly motivated to attack but did not do so.

19) Slight Open Mouth Smile

A. The mouth is open but not fully. Only upper teeth are exposed. The mouth corners are pulled upward. This has a crescent appearance.

B. a, when two children sittng near each other were looking at each other; $b$, when a child said, "Iya!" ("No!") to the observer as soon as the observer began to move a toy which he was using.

C. This 'smile' occurs in greetings between friends like the 'Close Mouth Smle,' in response to the pleasant stimuli (e.g., other's movement of gesture, music), and upon receiving a material reward. 20) Sad Frown

A. The inner ends of the eyebrows are raised so their appeararane becomes pyramidal.

B. a,one- to three-year-olds sometimes showed this behavior pattern when they encountered the observer in the early stage of this study.

C. 'Sad Frown' occurs too infrequently to infer its function. Children seem to show 'Sad Frown' when they look at strangers.

21) Slightly Open Mouth

A. There are no tension on the lips and the mouth is slightly open.

B. 1. When a child was paying attention to something: a, while standing aside and looking down at the other child who was lying and crying; $\mathbf{b}$, while looking at the curious movement of others (e.g., drama, pounding the rice cake); $\mathbf{C}$, while looking at an interesting thing (e.g., picture book).

C. The function of this behavior pattern is unknown. Children seem to show this behavior pattern when they concentrate only visually.

22) Square Mouth

A. The mouth is open almost more fully than that of 'Kidney Mouth.' The mouth corners are pulled outward and 
downward. The appearance is square- or trapezoid-like.

B. When children were crying.

C. 'Square Mouth' occurs simultaneously with 'Narrow Eyes,' 'Frown' and facing up during crying ocassionally among one- to three-year-olds. This complex seems to function both in making it easy to cry and in drawing a person's attention to the child.

23) Tightly Closed Mouth

A. The upper lip is pressed downward and the lower lip upward. The mouth is tightly closed. The mouth corners are pulled laterally. The lips are sometimes rolled into the mouth. The appearance of the lips is thin.

B. 1 . When a child was moving with all his might: a,pulling an object with a peer. 2. When looking at an other child: a, during lunch time, looking at the face of a peer sitting beside hlm; $\mathbf{b}$, while standing aside and looking at a peer who was climbing the fence.

24) Wide Eyes

A. The eyelids are more open than in normal position. The eyebrows are more or less raised so that they have an arched appearance.

B. a, when a child moved his head to look at a peer's face while the peer was gazing at him; b, when a child changed his eyes from the observer to the teacher.

C. 'Wide Eyes' occurs infrequently. However, it seems to be concerned with getting information rapidly from the obect at which he is gazing. This behavior pattern was not seen as fearful behavior as suggested by MCGREW (1972) nor as defensive behavior by BLURTON Jones (1968).

25) Wrinkled Nose

A. The skin of the nose is moved upward so that there are two types of wrinkling across the bridge of the nose; horizontal and wedge-shaped.

B. a,during meal time, a child showed a wedge-shaped 'Wrinkled Nose' while looking at an other child's face and saying, "Ne, Ne." (you see ?);b, while a child showed a "Slight Open Mouth Smile" to the observer.

C. This behavior pattern seems to occur $i_{n}$ various situations. The wedge-shaped type appears to occur simultaneously with'smiles' in this catalogue.

\section{DISSCUSSION}

How do the facial behavior patterns chage with child development? What are the cultural differences in children's facial behavior? These questions can be considered by means of comparing the behavior patterns of the differnt ages in the same culture (three age-classes in this study : nine months- to one-year-olds, one- to three and a half-year-olds, and three and a half- to five-year-olds); and by means of cross-cultural comparisons of behavior patterns of children of the same age.

At first, the behavior patterns of three and a half- to five-year-olds are compared with those described by MCGREw (1972). "Bared Teeth" and "Eyebrow Flash" are his items which are not listed in my catalogue. The latter behavior pattern was not observed in social surprise situations nor as friendly greeting as described by 
MCGREw(1972). The differencs between MCGREW's and my catalogue may be due to the cultural differences between Japan and England. For we cannot deny that culture may influence preschooler's behavior patterns. For instance SANo (1980:174) pointed out that it is from the age of 1.8 years that children show "Palm-down Beckon' which differs from "Beckon" with palm up described by MCGREw (1972) in the direction of the palm, in the same situation where both gestures apparently seem to mean "come near."

Three items of this catalogue; "Tightly Closed Mouth,' 'Asymmetrical Mouth' and 'Droop' are not listed in "Facial patterns" of McGREw(1972). 'Droop' seems to be included in "look" in which MCGREw (1972) included all the behavior patterns concerned with the eye direction. Since 'Tightly Closed Mouth' may correspond with "Lips pressed together" of Blurton Jones (1971), it may be possible that McGREw (1972) did not list this behavior pattern because of its frequency.

"Pucker Face" of McGrew (1972) is not in this catalogue. However, it can correspond with the combination of Kidney Mouth,' 'Square Mouth' or 'Mouth Corners Down' and 'Frown' or 'Sad Frown.' "Smile" of McGREW (1972) can correspond to 'Close Mouth Smile,' 'Slight1y Open Mouth Smile' and 'Open Mouth Smile.' The differences between McGrew's (1972) items and this catalogue's may reveal that McGREw's categorization is rougher than that of this catalogue, and seems to reflect the developmental changes of those behavior patterns: the situations where "Pucker Face" occurs decrease from one-year-old to five-year-old, and the cases of crying with face up decrease while those with face down increase.

A comparison is done between behavior patterns of children of different ages; nine months- to one-year-olds for Young and Gouin Dícarie (1977) and one- to three and a half-year-olds for this study. Though comparing different ages of different cultures connot be justfied, it might provide the knowledge of the developmental aspect of behavior patterns since the ages of the subjects of each study are continuous.

The items of Young and GouIn Décarie (1977) which are not in this catalogue are the "Ambivalent face," the "Frozen face," the "Lip roll," the "Tongue out," the "Undifferentiated face" and the " $\mathrm{Ne}$ gative face." "Frozen face," "Lip roll" and "Tcngue out" may be included in the repertoire of head patterns other than facial patterns. Other items could not be judged or could be judged in part by Young and GouIn DÉCARIE (1977) according to their own criteria. There are no items in this catalogue corresponding to those three items because the measurements of these expressions depended on the observer's judgements of the subtle differences of the emotions and was not employed in this study. 'Asymmetrical Mouth' is an item which is not in YounG and Gouin Décarie (1977) because they excluded behavior related only to older children and other emotions (e.g., a contemptuous sneer). It can be said that there may be a coincidence between the 
hedonic tone of each item judged by Young and GouIn DÉCARIE (1977) and inferred from this study (see Table 1). It can be concluded that there seems to be no addition nor disappearance of facial bebavior patterns along with the developmental process from one to five years of age though there is a possibility that children of one and a balf-years-old may have culturally influenced facial behavior paterns.

In order to analyze the situations where children actually show their behavior patterns, the catalogue of Young and Gouin DÉcarIE (1977) seems to be somewhat complex for an observer's recording without such equipment as the V.T.R. or films. On the oher hand, the MCGREW's (1972) list seems to be a little simple even if it was considered to be convenient for his research. This contrast in the type of categorization may be based on the difference between the emphasis on how all the facial expressions can be categorized for MCGREW (1972) and on what kinds of facial expressions can be observed in some situations for YounG and GouIn DÉCARIE (1977).

Other points derived from this etbological research are on the sequences and combinations of facial behavior elements and on the features of the mouth. The studies concerning the former point have not been adequately done though ZIVIN (1977) studied facial gestures which predict a preschooler's encounter outcomes. This kind of question is open to future ethologcal studies. One example concerned with the question is in this study. When there was pulling and taking away an object between two children, and then one's physical hit caused the other's crying accompanied by 'Nar row Eyes,' 'Spuare Mouth,' facing up and immobility of the body, the hitter immediately streched his arm, put his hand on the top of the other's head and rubbed it for a few seconds, especially among around one and a halfyear-old children. Such 'reassurance' behavior showed by the hitt eer who tried to take the object from the peer followed the display of the subordinate and did not function as literally since it did not seem to reduce the intensity of the other's crying expression, and has not been, however, noticed in the previous literature. Future work may have to solve the question of whether or not such reassurance behavior may exist crossculturally among preschool children and what the significance of this behavior may be.

The items of the mouth unit can be classified morphologically (Figure 1). It is possible that there is not only the contrast between the outward pulling and inward retracton of the mouth, and that the intensity of vocalization accompanied by the behavior pattern may change along the vertical axis. There seems to be the principle of antitbesis (DARWIN, 1872) in upward and downward pulling of the mouth corners as BRANNIGAN and HUMPHRIES (1972) nonted.

\section{ACKNOWLEDGEMENT}

I would like to express my appreciation to Dr.T.Nishida for his comments on earlier versions of this paper, which is 


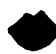

16 Pout (N)

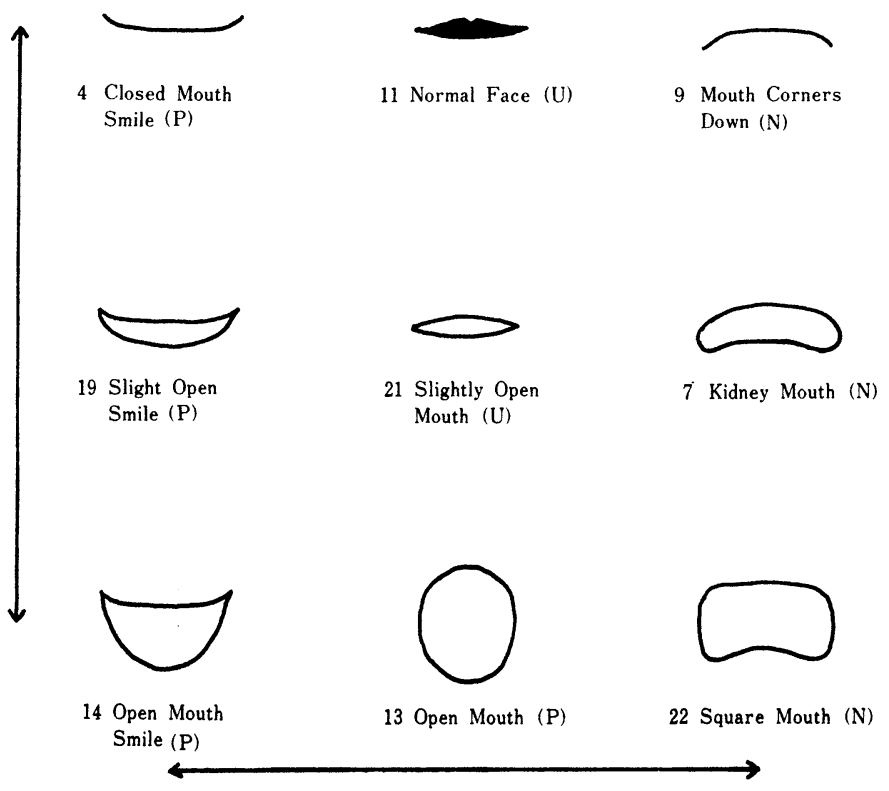

Fig. 1. The items of the mouth. $P, U$ and $N$ mean as in Table 1 .

mostly based on a part of the research for my master's degree. I thank the children and the staff of Kamirenjyaku Day Nursery for accepting the observer. I thank Carol Sbabrami for editing my English.

\section{REFERENCES}

Altmann, J. 1974: Observational Study of Behavior; Sampling Methods. Behaviour XLIX : 227-267.

Blurton Jones, N. 1967: An Ethological Study of Some Aspects of Social Behaviour of Children in Nursery School. In D. MORRIS (Ed.),
Primate Ethology, Aldine, Chicago, 347-368. 1971: Criteria for Use in Describing Facial Expressions of Children. Human Biology, 43: 365-413.

Brannigan, C., D. Humphries, 1972: Human Non-verbal Behavior, a Means of Communica tion. In N. BLuRTon Jones (Ed.), Ethological Studies of Child Behaviour, Cambridge Uniuersity Press, Cambridge, 37-64.

Chance, M.R. A. 1962: An Interpretation of Some Agonistic Postures; the Role of "Cutoff "Act and Postures. Symposia of the Zoological Societies of London, 8: 71-89.

DARWIN, C. 1872: The Expression of the Emotion in Man and Animals: a reprint of Ap- 
pleton Edition, University of Chicago Press, Chicago.

EIBL-Eibesfeld , I. 1975: Ethology, the Biology of Behavior 2nd ed., Holt, Rinehart and Winston, New York.

Grant, E. C. 1969: Human Facial Expression. Man, 4 : 525-536.

LoRENZ,K.1965: Evolution and the Modification of Behavior. University of Chicago Press, Chicago.

McGrew, W.C. 1972: An Ethological Study of Children's Behavior, Academic Press, New York.

SANO,T.1980: Hito no Yōji no Kōdōgaku-teki Kenkyu (An Ethological Study of Behavior of Day Nursery Children), Unpublished

日本人保育園児の顔面部の行動目録
Master's Thesis, University of Tokyo.

Tinbergen, N. 1963: On Aims and Methods of Ethology. Z.f. Tierpsychol., Bd. 20, Heft 4 : 410-433.

Young, G., T. Gouin DÉcarie, 1977: An Ethology-based Catalogue of Facial/Vocal Behaviour in Infancy. Animal Behaviour 25: 95-107.

ZIvin, G. 1977: Facial Gestures Predict Preschooler's Encounter Outcomes. Soc. Sci. Inform. 16: 715-730.

vaN Hooff, J. A. R. A. M. 1971:Aspects of the Social Behaviour and Communication in Human and Higher Non-human Primates. Bronder-Offsit, Rotterdam.

(Received July 3, 1982)

\author{
佐 野 敏 行 \\ 東京大学理学部人類学教室
}

動物行動学が行動目録を基盤にして発展したようにヒトを対象とする行動学あまず行動目録を整備する必要 がある。しかし今までのヒトの行動目録はヨーロッパ系白人をあとにつくられてきた。行動パターンの普遍性 及び文化による影響を知るには，非白人をむとに異なった文化において得られた行動目録が必要である。そて で日本人をもとにした行動目録を提示することが本研究の目的である。

本研究では，日本人の保育園児を対象に 480 時間にわたる直接観察及び V.T.R. による映像記録をもとに して顔面部における25項目の行動パターンを抽出した。各項目に定義，出現情況そして機能の推定などの記載 を行なった。また，顔面部における行動パターンの成長にともなう変化及び通文化的比較の観点から，白人を あとにした同様の研究結果との比較考察を行なった。

異文化における他の研究者の結果との比較によって得られる項目の違いは，主に研究者の項目設定の仕方に おける違いによるあのが多い。しかし行動パターンの出現情況に文化差が認められる可能性のあるあのがあっ た（目録番号 $12 ， 17 ， 24) 。 1$ 歳から 6 歳までの成長の過程で, とくに行動パターンの種類に変化はみられな かった。YOUNG and GouIN DÉCARIE (1977) が提示した彼らの抽出による行動パターンと「快一不快」 の尺度との関係は, 本研究の結果とよく合致し, 行動パターンと「快一不快」の尺度との間に通文化的共通性 のあることが推定できた。また本研究で観察された，泣かせた子どあが泣かされた子どあに対して示す「慰热」 行動は今までの文献になく，乙の行動の意味及び文化の影響に関して興味深い今後の研究課題であろう。

\section{佐 野 敏 行 東京大学理学部人類学教室 \\ 干113 東京都文京区本郷7-3-1}

Toshiyuki SANO Department of Anthropology,

Faculty of Science, University of Tokyo,

7-3-1, Hongo, Bunkyo-ku,

Tokyo 113 Japan 